\title{
How are the Performance of Small Businesses Influenced by HRM Practices and Governmental Support?
}

\author{
Yusra Y. Lazim \\ Noor A. Binti Azizan \\ Shahryar Sorooshian \\ University Malaysia Pahang \\ Email: yousra_yasin81@yahoo.com
}

Doi:10.5901/mjss.2015.v6n1p97

\begin{abstract}
Human resources have been regarded as the most important asset for any organization because of its essential part in achieving the sustainable competitive advantage and survival. Managing human resources is very challenging and requires an effective bundle of practices that contribute to attaining the organizational goals. This study tries to confirm the importance of HRM practices in small businesses which came to play a vital role in the economies of the world, through clarifying the influence of HRM practices on the organizational performance, using a mediating variable (employees' outcomes). Also the study attempts to highlight the key role of governmental support from view point of small businesses, through verifying the significant relationship between governmental support and the organizational performance. It was hypothesized that HRM practices will be positively related to the organizational performance (financial \& operational), and that employees' outcomes would serve as a mediator in the relationship between HRM practices and performance. Also it was hypothesized that the governmental support will be positively related to organizational performance. Structural Equation Modelling (SEM) with Amos has been applied in this research. The research sample consist (265) small manufacturing businesses in Malaysia. The statistical results showed significant relationships in direct and indirect models of study, and partially mediated in mediation models.
\end{abstract}

Keywords: Small businesses, HRM practices, employees' outcomes, governmental support, and organizational performance.

\section{Introduction}

All economic point of views has shown consensus about the growing importance of small business, whether in the industrially developed countries or developing countries.

In Malaysia, The importance of small businesses rises through its active contribution in generating income and value-added. In 2003, small businesses achieved a net income of RM 405 billion and RM 154 billion value added (UNDP, 2007). The latest statistics indicate that SMEs contribute $99.2 \%$ of the total business establishments, and contribute about $32 \%$ of GDP and 59\% of total employment (SME Annual Report, 2010/11).

Currently, small businesses are facing many challenges and problems due to rapid environmental changes represented by the diversity of the labor market, development of information systems, globalization, and the constant change in product demands. These hasty changes are confronted by the inability of most of these businesses to keep up with these changes as well as utilizing them in their favor, due to the weakness of available resources for small businesses such as (necessary funding, advanced information system and active human resource).

To achieve success, businesses in general and especially the smaller ones must have the ability to improve performance by creating products and new work strategies, reducing costs, improving quality and productivity (Luthans \& Sommers, 2005), through using available resources and facilities such as the human resources by focusing on the ways and means that can help improve the ability of the workforce.

Many researchers have called for taking care of HRM in small businesses of its decisive influence to creating and increasing knowledge, motivation, trust, involvement and commitment, which is reflected in turn as a source of sustainable competitive advantage. Huselid (1995) has confirmed the fact that HRM practices represent a single path that can be used by businesses to conform attitudes and behaviors of their employees in order to serve the desired goals through the creation of conditions that make their employees on a high degree of engagement and thus making all efforts 
to achieve the organizational objectives.

Studies mostly concentrated on HRM and its impact over organizational performance in large firms (Delancy \& Huselid, 1996; Huselid, 1995; Paul \& Anantharaman, 2003; Dean Hartog \& Verburg, 2004). However, few studies have looked at the influence of HRM practices over organizational performance in small businesses (Collins, Allen \& Wright, 2004, 2005).

The importance of HRM practices lies in their power to influence the organizational performance not directly but through the positive influence on the employees' performance known as (employees' outcomes).

Many studies have been conducted to examine the relationship between HRM practices and employees' outcomes which tend to have influence on the organizational performance, but a few of those studies were dedicated to small businesses. Also, many of those studies were devoted to examining the relationship between HRM practices and one variable of the employees' outcomes such as trust, commitment, engagement and involvement (Collins, Jackson \& Allen, 2005; Huselid, 1995; Becker \& Huselid, 1998; Wright \& Snell, 1998; Guest, 2000).

The study of Cornell University/ New York along with Gevity institution is regarded a pioneer study that highlighted the importance of human resources in small businesses, and on the effective strategies followed by HRM in these businesses and their impact on the employees' outcomes and then on the organizational performance (Collins, Jackson \& Allen, 2005).

Based on Cornell University study, the main objective of this study is to examine the relationship between HRM practices and organizational performance of small businesses through the mediator variable (employees' outcomes).

In spite of the growing importance of small businesses in the economies of most countries in the world, these businesses suffer many difficulties that limit their capabilities to succeed and withstand the challenges faced and which sometimes lead many to fail and withdraw from the market. These problems are seen in the difficulties of obtaining the necessary funding, legal restrictions and bureaucratic procedures that govern the work of these businesses and the lack of managerial qualifications which can deal with these constraints effectively, and the difficulty to take advantage of opportunities for innovation due to lack of the necessary skills to turn creative ideas into commercial products that bring profit back to the businesses ( Vinnell \& Hamilton, 1999; Cosh \& Hughes, 2003).

Based on their strong belief in the positive importance of small businesses, most countries (developed, transitional, and developing countries) undertook to put forward various programs and policies to support small businesses in order to improve their ability to grow and step up their performance in innovation, promoting managerial skills, and to adopt the best practices to improve the efficiency of their human resources.

Since independence Malaysia has achieved many national development goals and nearly all of the Millennium Development goals (MDGs). For example the MDGs target to reduce the proportion of the population living below the poverty line by $50 \%$ between 1990 and 2015 was achieved in 1999, when the poverty rate fell from $16.5 \%$ in 1990 to 7.5\%. By 2006 the poverty rate was just 5\%. The growth and development of small businesses in Malaysia have contributed significantly in creating employment and thus in reducing the poverty rate.

The full realization of the importance of small businesses may incite the government to set up several institutions, incubation centres and banks allocated to these businesses, such as NSDC, SMIDEC, MECD, HRD portal.

Malaysia has given priority to small businesses and developed policies that meet the development needs. Strategies of the Eight Malaysia plan (2001-2005) have focused on the development of small businesses operation in the manufacturing sector, and large allocations used in order to confront the basic challenges and problems facing the development of small businesses and through arrange of institutions.

Despite the fact that there is a broad governmental support for small businesses, the researches that concern with studying the influence of this support on the organizational performance for small businesses is still scarce, if not nonexistent. The need is still urgent to examine the feasibility of the various forms of governmental support for small businesses from the point of view of those businesses.

The main objectives of this study are: First, to assess the effect of human resources management practices on the organizational performance of small businesses through examining the causal order of the main variables (Human Resources Management, Employee Outcomes, and Organizational Performance) in an attempt to unfold the so-called "Black Box" to clarify the ambiguous relationship between human resources management practices and organizational performance; Second, to assess the vital contribution of governmental support to the organizational performance of small businesses.

The significance of the study lies in; First, this study tries to investigate the on how the HRM practices influence on organizational performance, rather than what are the practices of HRM that influence on organizational performance. Second, this study tries to draw attention to the importance of the role of governmental support to back up small businesses, and how some governments support small businesses to enhance their performance. 


\section{Literature Review}

Based on, the variables of study and the links among these variables. Researcher demonstrated the previous studies through four parts to support hypotheses of this study.Numerous studies are devoted to addressing organizational performance In order to determine the means of achieving high- level performance in organizations through putting strategies that are capable of helping organizations arrive at a high level performance. The present study addresses this issue relying on a model taken from Cornel University, with some modifications applied to that model by the researcher. The model of this study examines the effect of HRM on organizational performance through employees' outcomes at first, as well as the effect of the role played by the governmental support to small businesses on organizational performance, especially small businesses in Malaysia. The present study comprises four sections:

- The relationship between HRM Practices and organizational performance

- The relationship between HRM Practices and employee outcomes

- The relationship between employee outcomes and organizational performance

- The governmental support and its link to the performance of an organization

\subsection{HRM practices and its relation to organizational performance.}

During the 1990's, the field of management witnessed the introduction of a new factor which became the differentiator for businesses. What are meant by this factor are humans. Human resources started replacing products, markets cash, buildings and equipment and it became the main differentiator in businesses. Assets in a business are considered incomplete if they do not include human resources. Thus, such assets without human resources represent in fact passive resources which are unable to bring about the desired value without human resources practices. In fact, the major significant element that helps businesses to accomplish sustainable and profitable economy is workforce. However, there is some controversy regarding defining the concept of human resources management particularly if compared with personnel management practices of the past and industrial relations which play a significant role in theories of management adopted by the west.

Practices of human resources were first introduced during the early decades of the twentieth century. The period extending from 1950 up to the late 1970's witnessed a concentration by research literature on the expansion and development of human resources management practices in large businesses (Scott, 1915). The most contemporary literature relevant to HRM practices focuses on human resources management practices and their impact on the performance of an organization. Studies have shown a positive influence by HRM practices on company's performance. (Tenbrunsel at-al 1996); (Delery \& D.H. 1996); (Guest, 1997); (Huselid, 1995); (Huselid at-al, 1997); (Ichniowski at-al, 1997); (De Kok \& L.M. 2001); (Litz \& A. C. 2000); (MacDuffie 1995); (Schulze at-al, 2001); (Schulze at-al, 2003); (Welbourne \& Andrews 1996); (Wynarczyk at-al, 1993); (Arthur, 1994); (Ngo at-al, 1998); (Bae \& Lawler, 1998) ; (Fey \& Bjorkman, 2001); (Becker \& Gerhart, 1996) ; (Becker \& Huselid, 1997); (Gratton at-al, 1999); (Becker \& Huselid, 1998); (Paauwe, 2009); (Nishii \& Wright, 2008); (Guest at-al, 2003); (D'Annunzio-Green, 2002); (Richardson \& Thompson, 1999); (Voorde at-al, 2010).

Links between policies of human resources and business performance and the way human resources management practices influence company's performance may be shown through these precise mechanisms (Wright atal, 2003); (Purcell at-al, 2003); (Gerhart, 2007); (Becker \& Gerhart, 1996); (Ahlstron, 2005) What makes the scientists focus on the direct relationship between human resource management and company's performance is the difficulty and complexity of the statistical analysis in the indirect relationship. Hence, stemming from the above, we may arrive at the following hypothesis:

H1: Significant relationship between human resource management and organization performance.

\subsection{The relationship between HRM practices and Employee Outcomes}

Paul \& Anantharaman (2003) said in their study "it is more important to see "how" something is done compared with just "what" has been done", This sentence has been said to discuss the cause of high performance and human resource management applications, where it is important to study and discuss the steps of this relationship and the mediating or moderating variables overlapping between human resource management applications and organizational performance (Becker \& Gerhart, 1996); (Hutchison at-al, 2001). Employee skills like (cooperation and employee competences), employee behavior such as (presence, retention), and employee attitudes like (commitment, motivation, and satisfaction) is considered as classifications of outcomes of HRM (Appelbaum at-al, 2000). Those were commonly used as mediator 
variables (Paauwe, 2004). Therefore, researches which illustrate the results of human resources management as mediator variables also brought about the causal order models that explain the nature of relationships among the variables (Wright at-al, 2005).

It was debated whether organizational performance is improved and enhanced by direct mechanism usage of human resource management practices; that is to say, whether indirect effect of human resources management practices that are considered as alternative factors to increase the firm performance. This arising view assumes that the increase and decrease of organizational performance result from the outputs of employees in the organization such as trust, commitment as well as effort of involvement.

HRM has, in some literatures, been distinguished to (hard and soft) (Storey, 1992), or (low road and high road) of HRM that influence directly or indirectly in the performance of organizations. Employees' outcomes are motivated by effective human resources management practices, usage HRM practices efficiency and effectively derives to high level of employee outcomes (Guest, 1999); (O'Reilly \& Chatman, 1994); (Hame \& Prahalad, 1994); (Dess \& Picken 1999); (Steijn, 2004).

Indeed, two factors have an important and a vital role during the process of application of HRM. The first one is line managers, who have turned to play a wide role in HRM practices (Purcell \& Hutchinson, 2007) whereas the second factor is employees, as they represent the main target of human resources management practices aiming to arrive at a positive impact on organizational performance. In General, HRM studies have shown that employees tend to best perceive and experience the activities followed or adopted by their supervisors; (Paauwe \& Boselie, 2005) (Becker \& Huselid, 2006); (Bowen \& Ostroff, 2004); (Den Hartog at-al, 2004). This shows that the effect human resource management practices have on performance is at two levels; the level of the whole organization, and at the level of employees in the organization. The difference in the implementation of human resources management practices creates a different effect on both employees and organizations. Nishii \& Wright (2008) also mentioned the importance of the intended or designed human resources management system (what is implemented) and the perceived human resources management system (how individuals interpret it) to explain the HRM' effects on performance. Thus, the diversity of HRM process and HRM implementation from organization to organization may lead to contrasting outcomes with respect to employees' interaction and response.

During the last twenty years, literature relevant to HRM focused on finding an answer to essential points: Is the positive organizational performance made by human resources practices? Then, how is high level impact accomplished? The most recent discussions focus on the second question, because the issue is not only whether the practice of human resource management is a good thing for the organization or not. Causal relationships between the human resources practices and outcomes must be given more attention (Huselid \& Becker, 2005); (Barney 1991); (Appelbaum 2000); (Boxall \& Steeneveld 1999).

\subsection{Employee Outcomes and its relation to Organizational Performance}

It is commonly believed by specialists and practitioners of HRM that employees' performance owns critical entanglements on a company's performance (Huselid 1995). Nonetheless, in the recent years, focus on HRM practices that help achieve the highest employee performance, leading to maximum performance by the company, has increased. Specialists and researchers have suggested that when employees of a company perform collectively, this will lead to a major source of competitive advantage.

Some researches that related and based on resource-based view emphasize that people are the most importance assets to get to the success of the organizations especially in the competitive environment. In spite of what has been said by Michael Hammer about the human being "people our greatest asset" is not a factual issue in contemporary American business, human resources management is the term that has been known and the most famous in the literatures. HRM term has been the most comprehensive and expresses all practices that are concerned with the nature of people in all kinds of organizations (Collins \& Porras, 1994).

Numerous studies backed the suggestion that there is a strong relation between employees' outcomes which is satisfaction to performance (Judge, 2001); (Taris \& Schreurs 2009). A Survey has been done in UK by Guest and others from the Institute of Personnel and Development which included 610 companies, this survey tried to examine the nature of relationship between the HRM and performance, this study concluded that the linkage between human resources management and performance is indirect, due to the impact on employees quality, flexibility, and commitment (Guest, 2000). On the same tone Patterson \& colleagues (1997) Sheffield has conducted a considerable study, specified the vital role of HR practices on employees behavior and attitudes through some of employees' outcomes such as commitment and satisfaction of workforce that has a positive impact on organizational performance (Guest, 1999); (Nishii \& Wright 
2008); (Paauwe, 2009). So, there are many researchers, scholars and writers who suggested many models to demonstrate the indirect relationship between HRM and performance. For example, the model that has been proposed by Wright and Snell (1998) and the model that has been suggested by Becker and Huselid (1998), assert the policies of human resources management effect on employees' skills and behaviour which thereby influence the performance of firms. Nevertheless, there has not been a strong positive relationship in some studies that were conducted between mediating variables (Employees' Outcomes) and performance (O'Reilly 1991).

\subsection{The Governmental Support and its relation to Organizational Performance}

The government's support and its relation to organizational performance is of paramount importance to small businesses and this prompts most countries around the globe to adapt many kinds of programs to support small businesses and back them to encounter the several challenges they face.

In developed countries, the governments offer various supporting services (financial and nonfinancial), with strong belief in the vital role played by a small business in the development of their economies.

In developing countries, including Malaysia, the demand for governmental support increases because of barriers that face the small businesses.

In order to highlight the importance of the governmental support for small businesses and its role in the organizational performance, it is important to find and discuss some studies in this respect particularly in Malaysia.

Although the fact of existence of governmental support for small businesses, yet the literatures relating this subject are scarce, and almost are published by international and governmental agencies as reports statistically demonstrate the amount and kind of governmental support that are offered to small businesses.

There are many studies of governmental role in developed countries (Berry et-al, 2006); (lan \& Sure, 1998); (Jianzhong \& Hong, 2009); (Mole, et-al, 2009); (Schaper \& Vollery, 2004).

On the contrary, there are drought literatures pertaining to governmental support to small businesses in developing countries including Malaysia. MohaAsri (1997) assigns a chapter in this book to discuss briefly the government support.

Because the Enterprise plays a vital role in communities' prosperity through creating jobs, increasing technology and the competition in markets, adopting and developing innovative ideas, as well as increasing productivity, governments are supposed to support enterprises, particularly as they realize how a significant and vital role enterprises can play in economic growth. This support could be represented in working with the company to overcome the difficulties a company's performance and growth might face. In fact, several countries do focus on small businesses since the governments of these countries realize the vitality these small businesses have with respect to the overall economic growth of the country. Therefore, when these small businesses face difficulties, be them financial or others, governments run to help them overcome these difficulties.

There are many institutions that support small businesses, especially in the developed countries. Small businesses sometimes cannot get diverse sources, especially in relation to the financial assistance to start the project (Robinson, 1998). Financial institutions are trying to provide assistance, especially for projects that are held to help the poor in both vast areas and remote ones, and this means increased costs and difficulty in delivering services to all consumers in those areas, so the goal of these institutions is trying to reduce the cost as much as possible through outreaching to community groups (IBRF, 2002). One of the institutions that works to provide similar financial services and other services called microfinance which is recognized as a developmental tool due to its services such as Loans, tax breaks, pay a small rent, employment, counseling and advice, especially in the beginning of the establishment of a small businesses (Robinson, 1998).

SMEs are characterized by a number of attributes, but these characteristics are often considers disadvantages or problems, this is due to the nature of small projects (this is due to the nature of small projects) in terms of lack of human resources, material resources, administrative resources, and financial resources. Small businesses have trouble negotiating with customers and suppliers to get the best price and the liabilities and payment conditions more than big businesses, due to Trade name, brand, and large market share owned by large organizations. Small businesses also have limitations in the managerial resources, like the problems that relate to planning and organizing, where the difficulty of long term plans, the old methods used to organize work, given tasks and responsibilities, and to attract and motivate individuals and retention and last but not least, the lack of strategic vision of mangers of small businesses. Compared to large businesses, small companies have smaller and less complicated managements systems, with not as developed and up to date payment and reward arrangements. However, and despite the lack of resources that enables them of competing with large companies; these small businesses can become innovative. Many Small businesses plan to use and enhance government's support, which has a vital influence on their performance, in order to achieve the highest 
desired level of performance.

The Central Bank of Malaysia made a study in (2001) which brought to surface the difficulties that small businesses suffered from. According to this study, an enabling environment for small businesses development has been created to ensure the small businesses development plans are focused.

Khairudin (2007) focused on small businesses awareness about governmental support, particularly on credit guarantee scheme. The result of the study showed that only $10 \%$ of the respondents were aware of the services provided by the government.

Another study conducted by Mustafa, Khairudin \& Sha'ri (2006) demonstrated the financing approach to small businesses, source of financing and financial needs.

Another study about small businesses development in Malaysia Salleh \& Ndubisi (2006) stated the problems faced by the local small businesses which are related to business advisory services. The problems, among others, were:

- Lack of coordination among service providers.

- Low usage rate of governmental support services.

- Low level of knowledge on governmental support.

- Bureaucracy in the governmental agencies.

In another study conducted by Faziah, Aziz \& Sudin (2006) where they referred to usage of the governmental financial support services among small businesses in the northern part of Malaysia. While they found that most small businesses tend to ask for financial aids from commercial banks rather than the government support agencies. The lack of knowledge about the services and bureaucracy were two common contributing factors to the phenomenon.

Many studies showed similar results of the lack of awareness about governmental support among small businesses (Hakimin at-al, 2009); (Hakimin at-al, 2010); (Norliya at-al, 2010). A related study on the development of governmental supports was conducted by Rosli (2000). The study focused on the formulation of the government policy in supporting small businesses in the different phases of economic development.

In short, it is not easy to find some studies devoted to study the links between the governmental support and the organizational performance in small businesses. Therefore, this study will try hard to prove this relationship between government's role and the organizational performance in small businesses in Malaysia. It can be argued that the support presented by governments to small businesses stimulates them to achieve a higher level of performance. It can also say that among the most difficult challenges a small company faces is poorer governance Bellalah (2004); Zafft (2002).

\section{Research Model and Hypotheses}

This study consists of two parts, the first part devoted to examine the causal order of the relationship between HRM practices and organizational performance, by illuminating the indirect influence of the mediating variables that is so-called employees' outcomes (Intention to turnover, Effort of involvement, Cooperation, and Trust in management). The second part of the study dedicated to highlight the vital role of governmental support for small businesses, through testing the direct relationship between governmental support and organizational performance.

The model of this study had been adapted from the earliest model developed by Cornell University/ New York and Gevity institution, and had been examined on a sample of small businesses in USA in 2005. Also it had been tested on a sample of small businesses in Iraq in 2007.

To trace the causal order relationship between HRM practices and organizational performance the study examined how HRM practices affect organizational performance by inserting employees' outcomes as the mediating variables, considering that HRM practices can enhance these outcomes (Guest, 1997). Most theorists supposed that the causality relationship between HRM and performance (Becker, Huselid, Pickus \& Spratt, 1997; Delery \& Shaw, 2001; Edwards \& Wright, 2001). The general frameworks of direct relationships may observe between individual HRM practices and organizational performance (Schuler \& Jackson, 1999; Harel \& Tzafrir, 1999). But these relationships may not simultaneously present, and even the possibility of the absence of these direct relationship, some practices positively enhance organizational performance through the intervening process.

The success of any organization (including small business) depends on number of factors. The special characteristics which small businesses have and the difficulties that hinder their progress make them in dire need of governmental support. In Malaysia, government with its strong belief of the vital role of small businesses adopted many supporting programmes for backing up small business sector. As the review of literature about governmental support revealed that there is a scarcity of empirical researches devoted to trace the influence of governmental support on the organizational performance of small businesses, so as to clarifying the extent that small businesses benefit from the governmental support. The general model of study is as follow: 


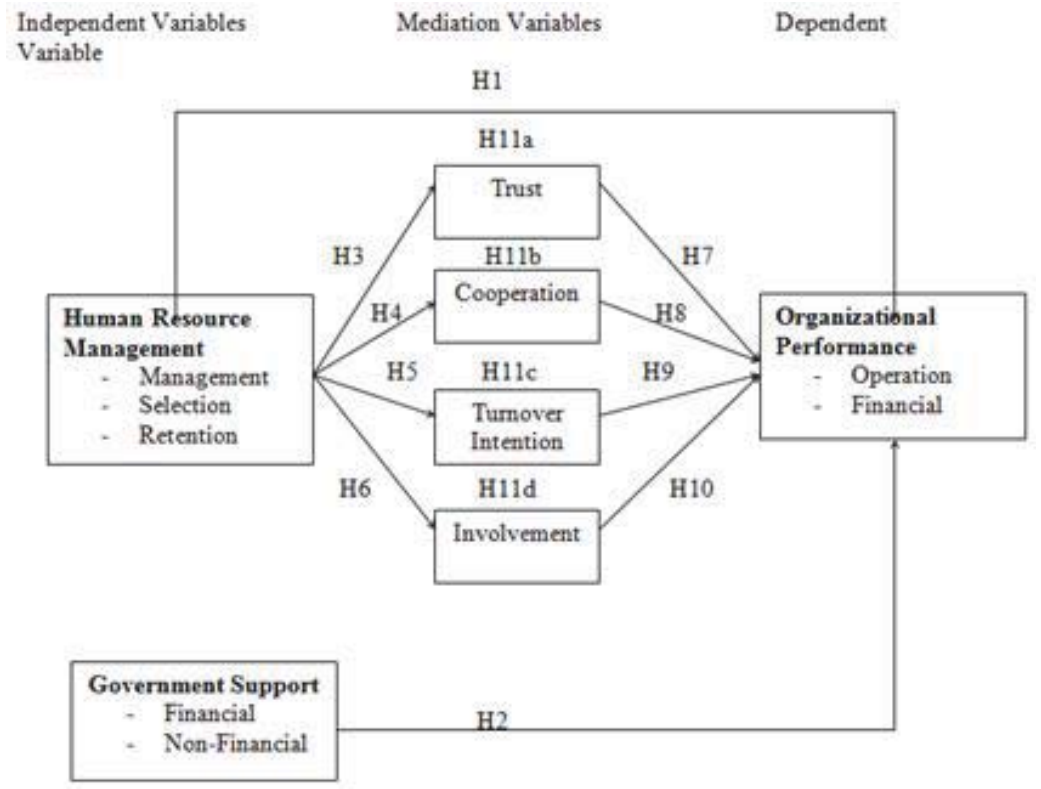

The arrows connecting between variables indicate the hypotheses to be tested, as following:

H1: Significant relationship between human resource management practices and organizational performance.

$\mathrm{H} 2$ : Significant relationship between governmental support and organizational performance.

H3, H4, H5, H6: Significant relationship between human resource management and (Trust in management, cooperation, Intention to turnover, and Effort and involvement.

$\mathrm{H} 7, \mathrm{H} 8, \mathrm{H} 9, \mathrm{H} 10$ : Significant relationship between (Trust in management, cooperation, Intention to turnover, and Effort and involvement) and organizational performance.

H11a, H11b, H11c, H11d: (Trust in management, Cooperation, Intention to turnover, and Effort and involvement) mediate the relationship between human resource management practices and organizational performance.

\section{Materials and Methods}

\subsection{Sample}

Sample of study includes 265 managers that have been chosen from small businesses in manufacturing sector in Malaysia which account approximately 15.796 (SEM report 2010/ 2011). Questionnaire was the main instrument for data collection. Team was organized by researcher included 129 undergraduate students to collect data from 265 respondents.

\subsection{Measures}

The measures in this study are HRM practices, Employee outcomes, governmental support, and organizational performance. All items of these variables are measured based on 5-point Likert scales of degree of agreement, 1 "Not agree completely" to 5 "Agree completely" as following details:

\subsubsection{HRM Practices}

HRM Practices are represented in this study as one bundle (Wright \& McMahan, 1992) by three key areas of selection practices including 8 items, Management Practices including 10 items, and Retention \& Motivation Practices including 10 items.

\subsubsection{Governmental Support}

Governmental Support was measured by two key areas of financial support including 4 items, and nonfinancial support 
including 6 items, these 10 items.

\subsubsection{Employee Outcomes}

The questionnaire items related to Employee Outcomes based on Collins et al (2005). Some modifications have been inserted to suit this study. The sub-variables are Intention to turnover, Effort of involvement, Cooperation, and Trust in management. Intention to turnover including 8 items, Effort of involvement including 4 items, Cooperation including 6 items, and Trust in management including 6 items.

\subsubsection{Organizational Performance}

Following the methodologies of Collins et al (2005), Organizational Performance has been classified to financial performance that includes 4 items and operational performance which includes 6 items.

\section{Statistical Analysis}

To test the hypotheses of the model of study, Structural Equation Modelling (SEM) or Latent Variable Model (Hair et al, 2010) was used by Amos. The most effective method to testing models which including latent constructs which multiple items (Luna-Arocas \& Comps, 2008). To a great extent the SEM used to test the validity of models. Through the Confirmatory Factor Analysis, but many applications of SEM are mix both of Exploratory Factor Analysis and Confirmatory Factor Analysis (Kline, 2010). Also, SPSS was used to find out the validity, reliability, normality, and descriptive analysis. Structural Equation Modelling is suitable for this study because:

- SEM is used to test 'complex' relationships between observed (measured) and unobserved (latent) variables and also relationships between two or more latent variables (Luna-Arocas and Comps, 2008).

- This study look into causal relationships, SEM represents causal processes that generate observations on multiple variables (Hair, et-al, 2010).

\section{Results}

\subsection{CFA Full Measurement}

Table 1 presented the CFA model after deleting items. Based on the result, the model fit indices reported that at least five fit indices were accepted for the CFA model as shown in Table 4.37 and Figure 8, with RMSEA $=0.043(p=.000)$, IFI = $0.905, \mathrm{CFI}=0.903, \mathrm{PGFI}=0.724$ and $\chi 2 / \mathrm{df}=1.493$.

Table 1 Summary of Model Fit for Full Measurement

\begin{tabular}{|cccccccccc|}
\hline Model & Chi-Square $\left(X^{2}\right)$ & Df & $X^{2} /$ df & RMSEA & GFI & IFI & TLI & CFI & PGFI \\
\hline Full CFA & 1170.542 & 784 & 1.493 & 0.043 & 0.833 & 0.905 & 0.893 & 0.903 & 0.724 \\
\hline
\end{tabular}

Although the chi-square is not significant ( $p$ value less than .05), the model still fits because Chi-Square statistic nearly always rejects the model when large samples are used (Bentler and Bonnet, 1980 and Jöreskog and Sörbom, 1993). One example of a statistic that minimises the impact of sample size on the Model Chi-Square is the chi-square value divided by the degree of freedom (Marsh and Hau, 1996 and Kline, 2010). If value divided by the degree of freedom is less than the value of 5 , the model fits reasonably well, and it a ratio does not exceed $3.0 ; \chi 2 / d f \leq 3$, a model demonstrates reasonable fit (Kline, 2010). In this study, the model shown the value of chi-square divided by the degree of freedom is $\chi 2 / \mathrm{df}=1.493$, so the model fit well. In addition, following the suggestion of Mueller and Hancocks (2008), the model fit well since RMSEA, CFI and $\chi 2 /$ df are very good fit. Based on correlation results in CFA model, it shows that the values are less than .85 , means that there was no case of multicollinearity.

\subsection{Structural Model}

To determine the best-fit model, three structural models namely direct (model 1), indirect (model 2) and partial mediation 
model (model 3) were tested for model comparison. The direct model (model 1) examined direct relationships from HRM practice, governmental support and organizational performance without going through the mediator variable (Trust in Management, Cooperation, Intention to Turnover, and Effort and Involvement). The indirect model (model 2) estimated paths from HRM practice and trust in management, cooperation, intention to turnover, and effort and involvement, and from trust in management, cooperation, intention to turnover and effort and involvement to organizational performance. Meanwhile, the partial mediation model incorporates all identified paths linking to organizational performance.

Table 2: Summary of model fit indices for Direct, Indirect and Mediation Model

\begin{tabular}{|lccccccccc|}
\hline Model & Chi-Square $\left(X^{2}\right)$ & $\mathrm{df}$ & $\mathrm{X}^{2} / \mathrm{df}$ & $\mathrm{RMSEA}$ & $\mathrm{GFI}$ & $\mathrm{IFI}$ & $\mathrm{TLI}$ & $\mathrm{CFI}$ & $\mathrm{PGFI}$ \\
\hline Direct & 1328.107 & 762 & 1.743 & 0.053 & 0.805 & 0.856 & 0.843 & 0.854 & 0.712 \\
Indirect & 1154.796 & 756 & 1.528 & 0.045 & 0.833 & 0.899 & 0.889 & 0.897 & 0.730 \\
Mediation & 1140.037 & 754 & 1.512 & 0.044 & 0.834 & 0.902 & 0.892 & 0.901 & 0.703 \\
\hline
\end{tabular}

In choosing structural model fit, based on the Model Comparisons in Table 2 shows the mediation model is most likely to represent a better model fit, since it presents batter fit indexes compare to the other models.

\section{Repot Hypotheses}

Table 3: Summary of Hypotheses

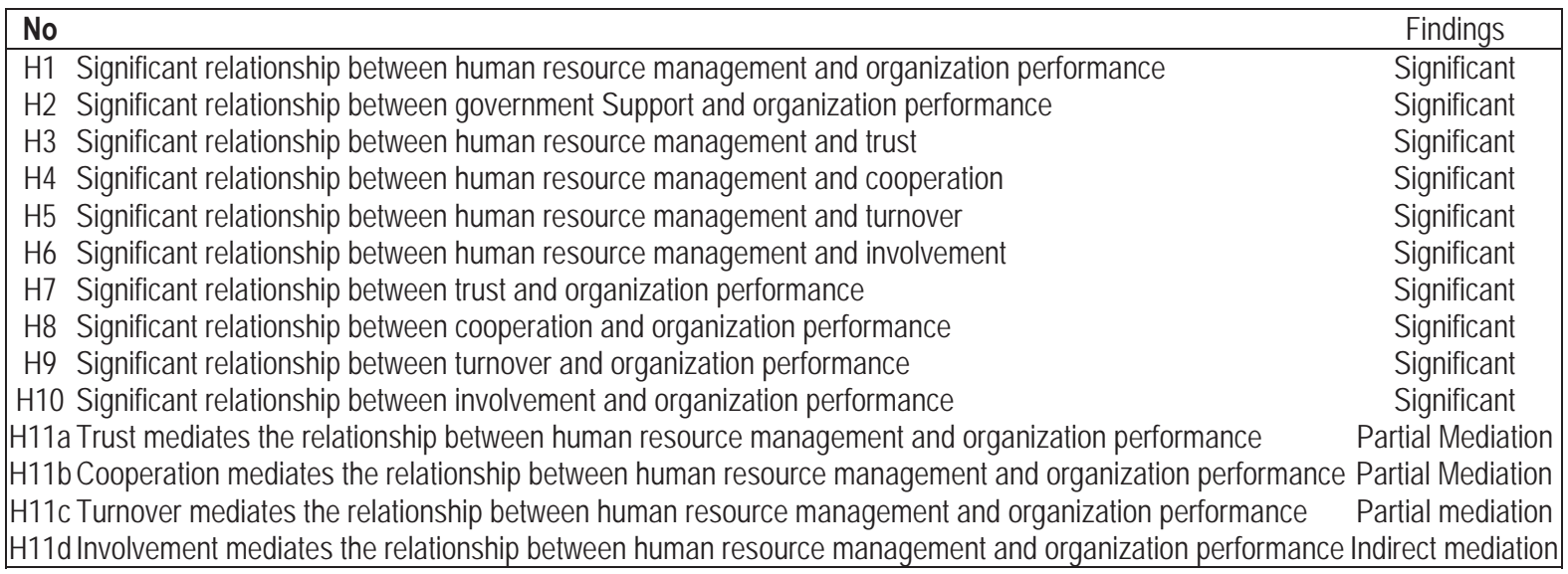

\section{Conclusion}

Small businesses are considered the cornerstone and the infrastructure of the economy in Malaysia, over the years, small businesses in Malaysia have evolved to become key suppliers and service providers to large businesses, inclusive of multinational and transnational businesses.

The importance of small businesses lies in their ability to supporting economic and social growth and activating the economic cycle, providing work opportunities and promoting policies aimed at combating unemployment and chronic poverty reduction, configuring value-added for an industrial domestic product, configuring forward and backward linkage for large firms through a network of supply, distribution, maintenance, and providing needed services to these firms, attracting small capitals, exploiting available resources, enhancing competitive forces and developing human and technical capabilities, and contributing towards to export and reducing important. In spite of the importance of small businesses in Malaysia, there are many obstacles that make these businesses fail and go out the markets.

\section{References}

Ahlstron, D., Foley, S., Young, M.N. and Chan, E.S. (2005). Human resource strategies in post WTO China. Thunderbird International Business Review, 47, 263-325.

Appelbaum, E., Bailey, T., Berg, P. and Kalleberg, A. L. (2000) Manufacturing advantage: Why high-performance work systems pay off. Economic Policy Institute: Cornell University Press, London. 
Arthur, J.B. (1994) 'Effects of human resource systems on manufacturing performance and turnover', Academy of Management Journal, 37(3), 670-687.

Bae, J. and Lawler, J.J. (1998) 'Variations in Human Resource Management in Asian Countries: MNC Home-country and Host-country Effects', International Journal of Human Resource Management 9: 653-670.

Barney, J.B. (1991). Firm resources and sustainable competitive advantage. Journal of Management, 17, 99-120.

Becker, B. E., and Huselid, M. A. (2006). Strategic human resources management: Where do we go from here? Journal of Management, $32,898-925$.

Becker, B.E., and Gerhart, B. (1996). The impact of human resource management on organisational performance: progress and prospects. Academy of Management Journal, 39, 779-801.

Becker, B.E., Huselid, M.A., Pickus, P.S. and Spratt, M.F. (1997) HR as a source of shareholder value: research and recommendations. Human Resource Management 36 (1), 39-47.

Bellalah, Mondher (2004). "On Investment Performance, Value Creation, Management and Corporate Governance: The French Case", Corporate Ownership and Control, 1(4), 72-80.

Bentler, P.M., \& Bonnet, D.C. (1980).Significance tests and goodness of fit in the analysis of covariance structures. Psychological Bulletin, 88(3), 588-606.

Berry, J., Sweating, R., and Gotu, J. (2006). The effect of business advice on the performance of SMEs. Journal of Small Business and Enterprise Development, 13(1), 33-47. http://dx.doi.org/10.1108/14626000610645298

Bowen, D.E. and Ostroff, C. (2004). Understanding HRM-firm performance link-ages: The Role of "Strength" of the HRM system. Academy of Management Review. 29 (2), 203- 221.

Boxall, P. and Steeneveld, M. (1999). 'Human resource strategy and competitive advantage: a longitudinal study of engineering consultancies'. Journal of Management Studies, 36: 4, 443-63.

Collins, Christopher, Ericksen, Jeff, and Allen, Mathew. (2005), "human resource management practices and firm performance in small businesses", research report on phase 3 of the Cornell university/Gevity institute study, Prepared by the Cornell Research Team September 2005.

Collins, J., and Porras, J. 1994. Built to last: Successful habits of visionary companies. New York: Harper Business.

Cosh, A. And Hughes, A. (2003). Enterprise Challenged: Policy and Performance in the British SME sector1999-2002, ESRC Centre for Business Research, University of Cambridge, Cambridge.

D'Annunzio-Green, Norma (Editor); Maxwell, Gillian (Editor); Watson, Sandra (Editor), (2002). The Impact of Strategic Human Resource Management on Organizational Performance, Emerald Group Publishing, Bradford, GBR.

De Kok, J.M.P. and L.M. Uhlaner, 2001, 'Organizational Context and Human Resource Management in the Small Firm', Small Business Economics 17 (4), 273-291.

Delery, J., and Shaw, J. 2001. The strategic management of people in work organizations: Review, synthesis, and extension. In G. Ferris (Ed.), Research in Personnel and Human Resources Management, Vol. 20. Oxford, UK: Elsevier Science.

Delery, J.E. and D.H. Doty, 1996, 'Modes of Theorizing in Strategic Human Resource Management: Tests of Universalistic, Contingency and Configurational Performance Predictors', Academy of Management Journal 4 (39), 802-835.

Den Hartog, D.N., Boselie, P. and Paauwe, J. (2004) 'Performance Management: A Model and Research Agenda', Applied Psychology: An International Review, 53:556-569.

Dess, G.D. and Picken, J.C. 1999. Beyond productivity: How leading companies achieve superior performance by leveraging their human capital. New York: American Management Association.

Edwards, P. and M. Wright (2001). "High-involvement work systems and performance outcomes: the strength of variable, contingent and context-bound relationships."

Fey, C.F. and Bjorkman, I. (2001) 'The effect of human resource management practices on MNE subsidiary performance in Russia', Journal of International Business Studies 32(1): 59-75.

Foziah, I., Aziz, L., \& Sudin, H. (2006). Entrepreneurs' awareness of bank borrowing offered by government agencies and commercial bank in Malaysia.

Gerhart, B. (1999) Human resource management and firm performance: Measurement issues and their effect on causal and policy inferences. In Strategic human resources management in the twenty-first century, (eds) P. Wright, L. Dyer, J. Boudreau and G. Milskovich. JAI Press, Stanford, CT.

Gerhart, B. (2007). Modeling HRM and performance linkages. In P. Boxall, J. Purcell, and P. Wright (eds). The Oxford Handbook of Human Resource Management. Oxford: Oxford University Press.

Gratton, Lynda et al., (1999). Strategic Human Resource Management, Oxford University Press, New York, p.7.

Guest, D. E. (1997), 'Human Resource Management and Performance: A Review and Research Agenda', the International Journal of Human Resource Management 8 (3),263-276.

Guest, D. Michie, J., Sheehan, M., Conway, N. and Metochi, M. (2000) Effective people management, Initial findings of the future of work study. London, Institute of Personnel and Development, 2000.

Guest, D., Michie, J., Conway, N and Sheehan, M. (2003). 'Human resource management and corporate performance in the UK'. British Journal of Industrial Relations, 41, 291-314.

Guest, D.E. (1999). Human Resource Management - the workers' verdict, Human Resource Management Journal. 3, 5-25.

Hair, J., Black, W., Babin, B., and Anderson, R. (2010).Multivariate data analysis (Seventh Ed.). New Jersey: Prentice-Hall. Inc.

Hakimin, Y., Dahlan, I., and Rafi, Y. (2010). The Sources of Information of the Government Sponsored Business Assistance Among 
Miro-sized Entrepreneurs in Kelantan, Malaysia. Paper presented at the 2nd ICIES, Jakarta.

Hakimin, Y., Rafi, Y., and Dahlan, I. (2009, 20 -24 March 2010). Business advisory: A Study on Selected Micro-sized SMEs in Kelantan, Malaysia. Paper presented at the 2nd International Conference on Arab-Malaysian Islamic Global Business and entrepreneurship, Jordan \& Syria.

Hamel, G. and Prahalad, C.K. (1994). Competing for the future. Boston: HBS Press.

Harel, H.G. and Tzafrir, S.S. (1999), "The effect of human resource management practices on the perceptions of organizational and market performance of the firm", Human Resource Management, 38(3), 185-99.

Huselid, M.A. (1995), 'The Impact of Human Resource Management Practices on Turnover, Productivity, and Corporate Financial Performance', Academy of Management Journal 38 (3), 635-672.

Huselid, M.A., S.E. Jackson and R.S. Schuler, 1997, 'Technical and Strategic Human Resource Management Effectiveness as Determinants of Firm Performance', Academy of Management Journal 4 (1), 171-188.

Huselid, Mark A., Becker, Brian E.. (2005). Improving Human Resources' Analytical Literacy: Lessons from Moneyball, Losey, Mike (Editor); Meisinger, Sue (Editor); Ulrich, Dave (Editor). Future of Human Resource Management: 64 Thought Leaders Explore the Critical HR Issues of Today and Tomorrow, John Wiley \& Sons, USA, p. 281.

Hutchison, S., Kinney, N. and Purcell, J.,(2001), "Bringing Policies to Life: discretionary behaviour and the impact on business performance", Paper Presented at the Bath conference, University of Bath School of Management, 10-11 April.

Ian, C., and Sue, B. (1998). Relationship influencers: determination of affect in the provision of advisory services to SME sector firms. Journal of European Industrial Training, 22(6), 249-256.

IBRF (The International Bank for Reconstruction and Development/The World Bank) (2002). World Development Report 2002: Building Institutions for Markets, Oxford University Press, New York, NY.

Ichniowski, C., C. Shaw and G. Prennushi (1997), 'The Effects of Human Resource Management Practices on Productivity: A Study of Steel Finishing Lines', American Economic Review 87 (3), 291-313.

Jianzhong, X., and Hong, F. (2009). An empirical study of usage of external business services by Chinese SMEs. Journal of Enterprise Information Management, 22(4), 423.

Jöreskog, K., and Sörbom, D. (1993). LISREL 8: Structural Equation Modeling with the SIMPLIS Command Language. Chicago, IL: Scientific Software International Inc.

Judge, T.A., Thoresen, C.J., Bono, J.E., and Patton, G.K. (2001). The job satisfaction-job performance relationship: a qualitative and quantitative review. Psychological Bulletin. 127, 376-407.

Khairudin, H. (Ed.). (2007). Small and Medium-sized Enterprises Development in Malaysia: Programs and Evaluation. Sintok: Universiti Utara Malaysia.

Kline, R. B. (2010). Principles and practice of structural equation modeling (3rd ed.). New York: Guilford Press.

Litz, A. and A. C. Stewart (2000), 'Research Note: Trade Name Franchise Membershipas a Human Resource Management Strategy: Does Buying Group Training Deliver'True Value' for Small Retailers?', Entrepreneurship Theory and Practice 25 (1), 125-135.

Luna-Arocas, R., and Camps, J. (2008). A Model of High Performance Work Practices and Turnover Intentions, Personnel Review, 37, 26-46.

Luthans, K. W., and Sommers, S. M. (2005). The impact of high performance work on industry-level outcomes. Journal of Managerial Issues, 17 (3), 327-345.

MacDuffie, J. P. (1995), 'Human Resource Bundles and Manufacturing Performance: Organizational Logic and Flexible Production Systems in the World Auto Industry',Industrial and Labour Relations Review 48 (2), 197-221.

Marsh, H. W., and Hau, K. T. (1996). Assessing goodness of fit: Is parsimony always desirable? Journal of Experimental Education, 64, 364-390.

Moha Asri, A. (1997). Industri Kecil di Malaysia. Kuala Lumpur: Dewan Bahasa dan Pustaka.

Mole, K., Hart, M., Roper, S., and Saal, D. (2009). Assessing the Effectiveness of Business Support Services in England: Evidence from a Theory-Based Evaluation. International Small Business Journal, 27(5), 557.

Mueller, R. O., and Hancock, G. R. (2008). Best practices in structural equation modeling. In J. W. Osborne (Ed.), Best practices in quantitative methods. Thousand Oaks, CA: Sage Publications, Inc.

Mustafa, Z., Khairudin, H., and Sa'ari, A. (Eds.). (2006). Business Practices in Malaysia Small and Medium-Sized Enterprises. Kedah: Universiti Utara Malaysia.

National SME Development Council (2005), SME Annual Report, Optimising Strategic Values.

National SME Development Council (2010), SME Annual Report, Leveraging Opportunities Realising Growth 2010/ 2011.

Ngo, H., Turban, D., Lau, C., and Lui, S. (1998) 'Human Resource Practices and Firm Performance of Multinational Corporations: Influences of Country of Origin', Journal of International Human Resource Management 9: 632-652.

Nishii, L.H. and Wright, P.M. (2008) Variability within Organizations. Implications for Strategic Human Resource Management. In: D.B. Smith, the People Make the Place. Dynamic Linkages between Individuals and Organizations. New York, Sussex: Taylor \& Francis Group.

Norliya, K., Siti Mashitah, A., and Siti Zaharah, H. (2010). Entrepreneurs' Information Need and Their in Managing Information. Paper presented at the 2nd International Conference on Arab-Malaysian Islamic Global Business and Entrepreneurship, Jordan \& Syria.

Normah Mohd Arjs (2006), "SMEs: Building Blocks for Economic Growth" Paper presented at the National Statistical Conference, Kuala Lumpur.

O'Reilly, C. (1991) Organizational Behavior: Where we've been and where we're going. In Martin Rosenzweig and L. Porter (eds.) 
Annual Review of Psychology, 42: 427-458. Palo Alto, CA: Annual Reviews.

O'Reilly, C.A. and Chatman, J.A. (1994) 'working smarter and harder: a longitudinal study of managerial success', Administrative Science Quarterly 39: 603-627.

Paauwe, J. and Boselie, P. (2005). HRM and performance: What next? Human Resource Management Journal. 15(4): 68-83.

Paauwe, J. (2004). HRM and performance: Achieving long-term viability. Oxford: Oxford University Press.

Paauwe, J. (2009). HRM and Performance: achievements, methodological issues and Prospects. Journal of Management Studies 46 (1): $129-142$.

Paul, A.K., and Anantharaman, R.N. (2003). Impact of people management practiceson organisational performance. International Journal of Human Resource Management, 14, 1246-1266.

Purcell, J., and Hutchinson, S. (2007). Front-line managers as agents in the hRMperformance causal chain: theory, analysis and evidence. Human Resource Management Journal, 17, 3-20.

Purcell, J., Kinnie, N., Hutchinson, S., Rayton, B. and Swart, J. (2003) Understanding the people and performance link: Unlocking the black box. Chartered Institute of Personnel and Development, London.

Richardson, Ray, Thompson, Marc, (1999). The Impact of People Management Practices on Business Performance: A Literature Review, Institute of Personnel And Development, Great Britain, p.xi.

Robinson Marguerite S (1998) The Paradigm Shift From credit Delivery to Sustainable Financial Intermediation, In Mwangi S Kimenyi, Robert C Wieland and J D Von Pischke (eds), 1998, Strategic Issues in Microfinance. Ashgate Publishing: Aldershot.

Salleh, A. S., and Ndubisi, N. O. (2006). An Evaluation of SME Development in Malaysia. International Review of Business Research Papers, 2(1), 1-14.

Schaper, M., and Vollery, T. (2004). Entrepreneurship and Small Business: A Pacific Rim perspective: John Wiley \& Sons Autralia, Ltd.

Schulze, W. G., Lubatkin, M. H., and Dino, R. N. (2003), 'Toward a Theory of Agency and Altruism in Family Firms', Journal of Business Venturing 18, 473-490.

Schulze, W. G., Lubatkin, M. H., Dino, R. N., and Buchholtz, A. K. (2001), 'Agency Relationships in Family Firms: Theory and Evidence', Organization Science 12 (2), 99-116.

Scott, W. D. (1915), 'The Scientific Selection Salesmen', Advertising and Selling 25, 5- 6, 95-96.

Steijn, B. (2004). Human Resource Management and Job Satisfaction in the Dutch Public Sector. Review of Public Personnel Administration. 24(4), 291-303.

Storey, J. (1992). Developments in the management of human resources. Oxford: Blackwell.

Taris, T.W. and Schreurs, P.J.G. (2009). Well-being and organizational performance: An organizational-level test of the happyproductive worker hypothesis. Work \& Stress. 23(2), 120-136.

Tenbrunsel, A. E., T. L. Galvin, M. A. Neale and M. H. Bazerman (1996) Cognitions in Organizations, in S. R. Clegg, C. Hardy and W. R. Nord (eds.), Handbook of Organization Stuies, London: Sage.

UNDP, (2007), Malaysia Small and Medium Enterprises Building an Enabling Environment, United Nations Development Programme, Kuala Lumpur.

Vinnell, R. and Hamilton, R. T. (1999), A Historical Perspective on Small Firm Development, Entrepreneurship Theory and Practice, 23(4), 5-18.

Voorde, Van De, Paauwe K. J., Van Veldhoven, M., (2010). "Predicting Business Unit Performance Using Employee Surveys: Monitoring HRM-Related Changes", Human Resource Management Journal, 20(1), 44-63.

Welbourne, T. M., and Andrews, A. O., (1996), 'Predicting the Performance of Initial Public Offerings: Should Human Resource Management be in the Equation?', Academy of Management Journal 39, 891-919.

Wright, P. M. and Snell, S. A. (1998) toward a unifying framework for exploring fit and flexibility in strategic human resource management. Academy of Management Review 23, 756-772.

Wright, P. M., \& McMahan, G. C. (1992). Alternative theoretical perspectives for strategic human resource management. Journal of Management, 18, 295-320.

Wynarczyk, P., R. Watson, D. J. Storey, H. Short, and K. Keasey (1993), 'The Managerial Labour Market in Small and Medium Sized Enterprises' London: Routledge, citedin Storey, Understanding the Small Business Sector, 150, 311.

Zafft, Robert (2002). "Large, Family -Run Firms: the OECD Experience", The Fourth Asian Roundtable on Corporate Governance, Shareholder Rights and the Equitable Treatment of Shareholders, OECD, Mumbai,India, 11-12 November. 